\title{
CONTINUOUS QUALITY IMPROVEMENT (CQI) FRAMEWORK: A CASE OF INDUSTRIAL ENGINEERING DEPARTMENT
}

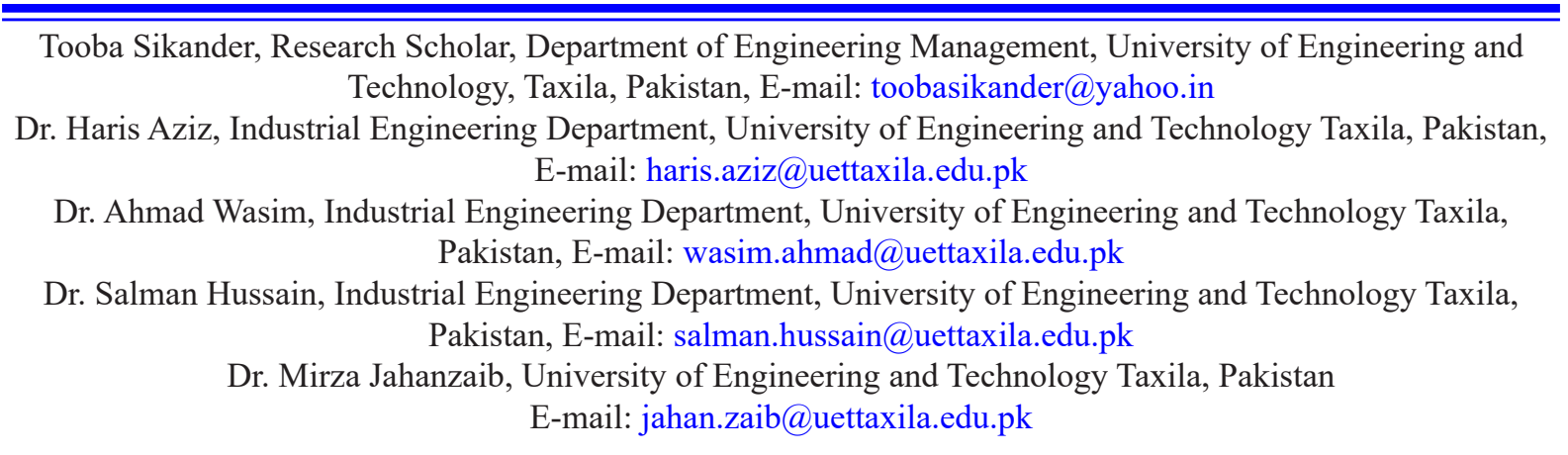

ARTICLE INFO

Original Research

Received: October, 31.2016.

Revised: December, 21.2016.

Accepted: January, 01.2017.

doi:10.5937/IJCRSEE1701107S

UDK

378:006.83(549)

\section{Keywords:}

Outcomes based education, continuous quality improvement framework, Bloom's Taxonomy, Outcomes based accreditation, program learning outcomes, course learning outcomes.

\begin{abstract}
A B S T R A C T
This paper aims to present an educational framework for outcomes based continuous quality improvement. Well defined program outcomes, program educational objectives and assessment process have been developed to ensure graduates' outcomes achievement. Direct and indirect tools have been used for assessment process. Course evaluation surveys, alumni surveys, and employer surveys have been deployed for indirect outcome assessment. Exams, quizzes, assignments and projects, on the other hand, have been used for direct outcome assessment. In developed framework, the educational processes committees and facilities committees have been integrated to continuously evaluate and monitor the educational processes. Furthermore, program outcomes and course learning outcomes are proposed to be evaluated and continuously monitored by programs goals committee and continuous course improvement committee respectively. Forms and procedures have been developed to assess student outcomes.
\end{abstract}

\section{INTRODUCTION}

International engineering alliance (IEA) gave a signatory status of Washington Accord (WA) to Pakistan Engineering Council in 2010. (Manual of accrediation Engineering Accrediation Board, 2014). Before 2002, the Washington Accord was based on conventional education system widely known as input based education system. The major problem associated with conventional education system was non-provision of feedback; which was major hindrance in continuous quality Corresponding Author

Dr. Mirza Jahanzaib, University of Engineering and Technology Taxila, Pakistan,

E-mail: jahan.zaib@uettaxila.edu.pk

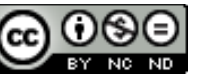

This work is licensed under a Creative Commons Attribution - NonCommercial - NoDerivs 4.0. The article is published with Open Access at www.ijcrsee.com
(C) 2017 IJCRSEE. All rights reserved.

improvement (Patil and Codner, 2007). After the identification of drawbacks in conventional education system, Washington Accord adopted outcome based education system in 2002 (Laguador and Dotong, 2014). After obtaining signatory status in 2002, Pakistan Education Commission faced the major challenges of conversion of their education system from conventional to outcome based system.

To overcome this issue, there was a need of continuous quality improvement framework for outcome based education implementation. The framework was required to integrate course objective, curriculum mapping, direct/ indirect measure and continuous course quality improvement (CCQI) as a single entity.

The paper aims to propose a continuous quality improvement framework for engineering education in Pakistan. The paper is structured as follows. Literature review has been presented in Section 2. Section 3 describes the methodology adopted for the development 
of framework. The proposed framework has been provided in Section 4.

Section 5 presents the results and analysis obtained by the application of proposed framework for a specific course. Finally Section 5 and 6 present conclusions and recommendations respectively.

\section{LITERATURE REVIEW}

Outcome based education is a newly developed model for the improvement of quality education. (Rajaee et al., 2013). It focuses on teaching and learning based on desired student's learning outcomes (Spady, 1994). To achieve these outcomes, assessment and performance standards have been designed and implemented (Spady, 1994). Literature review highlights the significance of outcome based education (Borsoto et al., 2014). Furthermore it serves as competitive advantage among different countries (Spady, Marshall and Kit, 1991).

In past centuries, two major education systems have been proposed namely (i) problem based learning, and (ii) project based learning. Problem based learning is a student centered learning approach. It encourages teachers to be facilitators instead of disseminators. It is based on open ended problems which serve as initial stimulus (White, 2001). Project based learning, on the other hand, aims to engage students in authenticated problems investigation. It is based on project with the objective to provide learning (Blumenfeld et al., 1991). Both traditional educational systems focus on contents with predefined curriculum and assessment system. Outcomes based education system, on the other hand, is relatively a new system which is based on defined framework for outcomes (Spady, 1994) i.e. it focuses on student's outcomes and skills they must possess in future (Spady, Marshall and Kit, 1991). In this system, curriculum, assessments, instructional strategies and performance standards are developed and implemented to meet desired outcomes (Spady, 1994).

Outcome based education includes (i) program educational objectives (PEO's), (ii) program learning outcomes (PLO's), (iii) stakeholders involvement in defining PEO's and PLO's, a well curriculum development to achieve desired program educational objectives and program learning outcomes, (iv) courses mapping to program educational objectives and program learning outcomes for contribution and development of continuous improvement process (Rashid, 2012).

Program educational objectives describe career and professional success that students attain after graduation (Manual of accrediation Engineering Accrediation Board, 2014). It is classified in to six categories namely (i) knowledge, (ii) comprehension, (iii) application, (iv) analysis, (v) synthesis and (vi) evaluation (Student Outcomes and Program Educational Objectives, 2015). Program learning outcomes have to be attained by students at the time of degree completion and must be specific, measureable, achievable, realistic, and time-based (Kapfer, 1971).

Assessment is the third step which aims to defining clear and measureable outcomes, ensuring opportunities to achieve these outcomes, implementing an evaluation system and then use results from evaluation for student learning improvement (Bresciani, 2006). Many direct and indirect assessment tools have been proposed in literature. Direct assessment tools include course assessment, student satisfaction survey, cumulative GPA index for course, basic exams, senior design project, and program accreditation (Sekhar et al., 2008). Senior exit survey is an indirect program outcomes assessment tool (Othman et al., 2011). Teacher evaluation is a tool that can be used for the evaluation of teacher performance (Chalmers and Gardiner, 2015) by student feedback which helps to improve teaching skills. Teacher training programs are also designed on the basis of evaluation which aid to enhance teachers' performance (Boerbooma et al., 2015). Rubrics is another indirect assessment tool that can be used for student's skills and course assessment (Almarshoud, 2011). Core indicators affecting academic institution are prioritized in three layers. Leadership, quality of faculty and infrastructure facilities reside at first layer. Quality of students, research, and learning environment are in second layer followed by strategic planning, governance, assessment procedures and market force as the third layer (Jahanzaib and Akhtar, 2005).

Review of literature presents that there exists a number of outcome based education models and continuous improvement frameworks. Bloom and his colleague Maser worked on behavioral objectives and developed taxonomies of the objectives for cognitive and effective domain (King and Evans, 1991). Davis adopted Carroll and Bloom's work to achieve desired educational reform (Davis, 2003). The developed framework con- 
sists of three phases. First phase of framework involves program and course objectives development; Second phase includes defining student learning outcomes based on Bloom's taxonomy of cognitive domain followed by third phase involving assessment workshops to familiarize faculty and administration with assessment techniques (Mcgourty et al., 2002). Besterfield proposed a conceptual model for quality improvement in engineering education and developed program outcomes using affinity diagrams (Besterfield-sacre, Shuman, and Wolfe, 2002). Volkwein, Lattuca and TereNzini developed a conceptual framework to examine impact of ABET's EC200 impact on student's learning outcomes (Volkwein, Lattuca, and TereNzini, 2004). Malaysian institute of information and technology developed a computerized system to link, asses and measure course learning outcomes and program learning outcomes (Mokhtar et al., 2014). Beside these typical assessment models a new program outcomes assessment model focusing on performance criteria for each program outcome. The researcher discouraged the use of grades as performance indicators (Mohammad and Zaharim, 2012). A continuous improvement program based on outcomes based education comprised of student's outcomes assessment tools have been developed and implemented by Sekhar, C. R. et all. (2008). An outcome driven hybrid academic model was proposed by Bouslama et al (2003). It uses grade point average along with outcomes driven students output. The model consists of learning outcomes, use of e-portfolios to record student achievement, assessment and its reflection and closed feedback learning communities.

From the detailed literature review, it can be seen that number of authors have proposed outcome based education implementation models. However, it must be noted that systematic implementation of framework is required to fully achieve objectives of outcome based education. Engineering education institutions in Pakistan are bound to follow outcome based education in true spirit to get accreditation from Pakistan engineering commission. Therefore this research has proposed outcome based education continuous quality improvement framework. This will help the engineering institutions in Pakistan to apply outcome based education in true manners.

\section{METHODOLOGY}

This research explores the continuous quality improvement framework for outcome based education implementation in engineering institutions of Pakistan. The methodology consists of five phases. Literature review has been conducted in first phase to identify the limitations of previously developed frameworks. After identifying the gaps in phase 1, a framework has been proposed in phase 2 . The framework aligns the classroom practices and educational structure. A specific course was selected in phase 3 for the implementation of framework. Analysis of the course assessment data was conducted during phase 4. Finally, improvement methodology was suggested in phase 5 for continuous quality enhance.

\section{PROPOSED FRAMEWORK}

An outcomes assessment and continuous improvement framework based on above mentioned methods are proposed to ensure program educational achievement. The proposed framework has been presented in figure 1.

The proposed framework consists of three modules namely (i) Outcome module, (ii) management module and (iii) assessment module. Outcome module defines the targeted outcomes and it consists of program educational outcomes, program earning outcomes and course learning outcomes. Assessment module assesses the fulfillment of the targeted outcomes based on certain criteria. Management module consists of monitoring and evaluation committees for continuous improvement. Three suggested committees are: (i) Continuous course improvement committee (CCI), (ii) program goals committee (PGC) and (iii) education facilities and processes committee (EFPC).

Significant feature of proposed framework is indicated by three layers of outcomes assessment cycles.. These cycles includes (i) course learning outcomes assessment, evaluation and continuous improvement cycle, (ii) program learning outcomes assessment, evaluation and continuous improvement cycle and (iii) program educational objectives assessment, evaluation and continuous improvement cycle.

First cycle encloses course learning outcomes assessment and improvement cycle. Closing the loop takes sixteen weeks (one semester). The second cycle program outcomes 
assessment cycle is a slow process and takes one year. Third cycle is program educational objectives assessment and improvement which is also slow in nature. This cycle take four years to close it. Stakeholders (students, alumni, industry, parents, and faculty) provide input in form of surveys, gathered data is analyzed to review and modify PEO's and PLO's.

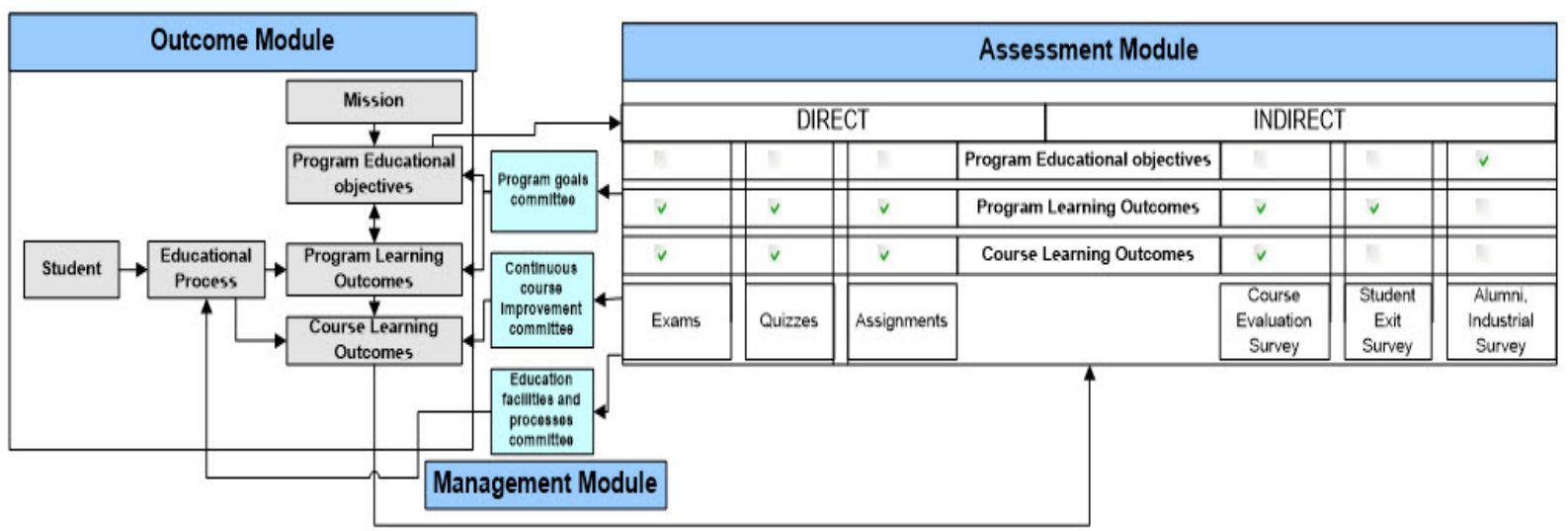

Figure 1. Outcomes Based Education Continuous Quality Improvement framework

Outcomes Assessment methods used to evaluate outcomes according to developed framework are direct assessment and indirect assessments. Direct assessment includes outcomes assessment (e.g. course learning and program learning outcomes). Indirect assessment, on the other hand includes student's course completion survey, exit survey, alumni survey and employer survey

These assessment processes may be used to improve outcomes, course contents, curriculum and educational processes to achieve targeted outcomes. Teacher evaluation survey may be used to evaluate teacher performance.

Following sections explains the implementation of the proposed framework for course assessment and continuous improvement. The implementation starts with setting target outcomes (PEO, PLO and CLO), PLO/ CLO mapping, assessment and feedback for improving outcomes. All procedures been discussed separately below.

\subsection{Setting target outcomes}

This step involves setting target program educational outcomes, program learning outcomes and course learning. Program learning outcomes are statements which detail skills and abilities undergraduate students must achieve at time of degree completion. Program educational objectives and program learning outcomes have been developed as per Pakistan engineering council's guidance and are presented in table 1. Each course in the entire industrial Engineering curriculum contributes to achieve some or many of the program learning outcomes. Correlation of current Industrial engineering courses with program learning outcomes has been presented in Annexure 1. For more detailed analysis, correlation of program learning outcomes of one of the selected course "Metal forming and cutting analysis" is shown in table 2. 
Table 1. Program educational objectives and program learning outcomes

\begin{tabular}{|c|c|}
\hline \multicolumn{2}{|r|}{ Program Educational Objectives } \\
\hline a. & $\begin{array}{l}\text { To produce Industrial Engineers who assume challenging managerial and leadership roles in Manufac- } \\
\text { turing and Service sectors both at National and International Levels }\end{array}$ \\
\hline b. & $\begin{array}{l}\text { To provide Employers with graduates who remain at forefront and are technically competent; have inter- } \\
\text { personal, decision making and problem solving skills to enhance effectiveness }\end{array}$ \\
\hline c. & $\begin{array}{l}\text { To produce professionals who recognize that engineering is a global service profession that must be } \\
\text { practiced ethically, with integrity, honesty, and objectivity }\end{array}$ \\
\hline \multicolumn{2}{|r|}{ Program Learning Outcomes } \\
\hline a. & $\begin{array}{l}\text { Engineering Knowledge: An ability to apply lnowledge of mathematics, science and engineering to } \\
\text { solve complex problems. }\end{array}$ \\
\hline b. & Problem Analysis: An ability to identify, formulate, solve and analyze engineering problems. \\
\hline c. & $\begin{array}{l}\text { DesignDevelopment of Solutions: An ability to design a system, component, or process to meet desired } \\
\text { needs within realistic constraints such as economic, environmental, social, political, ethical, health and } \\
\text { safety, manufacturability, and sustainability. }\end{array}$ \\
\hline d. & $\begin{array}{l}\text { Investigation: An ability to investigate complex engineering problems systematically such as literature } \\
\text { review, design and conduct experiments, analysis and interpretation of experiments to derive valid con- } \\
\text { clusion }\end{array}$ \\
\hline e. & $\begin{array}{l}\text { ity to create, select and apply appropriate techniques, skills, and modem en- } \\
\text { engineering practice }\end{array}$ \\
\hline f. & $\begin{array}{l}\text { The Engineer and Society: An ability to apply reasoning informed by contextual knowledge to assess } \\
\text { societal, health, safety, legal and cultural igques and the consequent responsibilities relevant to profes- } \\
\text { sional engineering practice and solutions to complex engineering problems }\end{array}$ \\
\hline $\mathrm{g}$. & $\begin{array}{l}\text { Environment and Sustainability: An ability to understand the impact of engineering solutions in a } \\
\text { global, economical, societal context, environmental and sustainable development }\end{array}$ \\
\hline h. & lethical a \\
\hline i. & ely as an individual or in a team \\
\hline 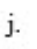 & Communication: An ability to communicate effectively \\
\hline k. & $\begin{array}{l}\text { Lifelong Learning: An ability to recognize the need for imnovation and technological development and to } \\
\text { engage in life-long leaming }\end{array}$ \\
\hline 1. & $\begin{array}{l}\text { Project Management: An ability to apply concepts of industrial system and process design, ergonomics, } \\
\text { engineering management, product development/manufacturing and analysis tools to work in a team ef- } \\
\text { fectively and to manage projects in multi disciplinary environments }\end{array}$ \\
\hline
\end{tabular}

Table 2. Program learning outcomes for Metal forming and cutting analysis

\begin{tabular}{ll}
\hline PLOs & \multicolumn{1}{c}{ PLOs Statements } \\
\hline PLO 1:a & an ability to apply knowledge of mathematics, science and engineering to solve complex problems \\
PLO2:b & an ability to identify, formulate, solve and analyze engineering problems \\
PLO3:c & an ability to design a system, component, or process to meet desired needs within realistic constraints \\
& such as economic, environmental, social, political, ethical, health and safety, manufacturability, and \\
& $\begin{array}{l}\text { sustainability } \\
\text { an ability to create, select and apply appropriate techniques, skills, and modern engineering tools } \\
\text { PLO4:e }\end{array}$ \\
\hline
\end{tabular}

A set of measureable course learning outcomes are required to drive the course. A sample of course learning outcomes developed for the course "Metal forming and cutting analysis" are shown in table 3. CLO's are developed on account of skills students must possess by the course completion. Course experts took sixteen weeks to deliver course contents assisting achieve course learning outcomes. 
Table 3. Course learning outcomes for Metal forming and cutting analysis

\begin{tabular}{ll}
\hline CLO's & \multicolumn{1}{c}{ CLO's statements } \\
\hline CLO 1 & $\begin{array}{l}\text { Recalling the concepts of Manufacturing } \\
\text { Processes for in-depth knowledge of pro- } \\
\text { standing }\end{array}$ \\
\hline CLO 2 & $\begin{array}{l}\text { Identification of the known parameters in } \\
\text { forming and cutting processes and making } \\
\text { efficient use of boundary conditions AP- } \\
\text { PLY }\end{array}$ \\
\hline CLO 3 & $\begin{array}{l}\text { Be able to apply related conditions (of } \\
\text { parameters) and obtaining an appropriate }\end{array}$ \\
& UATE \\
\hline CLO 4 & $\begin{array}{l}\text { Reinforce evaluation capability for fur- } \\
\text { ther synthesis of problems in metal form- } \\
\text { ing cutting analysis for creation of prod- } \\
\text { ucts if any CREATE }\end{array}$ \\
\hline
\end{tabular}

\subsection{Correlation between Program learning outcome and course learning outcome}

Correlation assessment between course and program learning outcome allow program to know course contribution to outcomes but it do not allow assessment of specific outcomes achievement. For its assessment program learning outcomes are divided into number of measureable statements to identify student's performance required to meet outcomes. These measureable statements are called performance criteria. For example PLO $\mathrm{j}$ "an ability to communicate effectively" would require criteria i.e. (i) effective presentation (ii) effective writing (iii) professional communication mastery. These three criteria require three types of assessments and measurement.

Graduate must achieve all program outcomes by the end of degree completion which calls for a procedure to measure program learning outcomes by course completion. To measure PLO's course learning outcomes are mapped to program learning outcomes by a linking matrix. In this way PLO's are measured by accumulated sum of CLO's. For continuous improvement course learning level monitoring is required to make sure contents delivered and assessed are in accordance with course com- plexity level or vice versa so, course learning outcomes (CLO's) are mapped with Bloom's taxonomy. In addition, course contents, teaching methods and assessment methods need to be documented and continuously monitored. Student satisfaction surveys conducted after course completion assist teaching learning methods, assessment methods and course contents continuous improvement where as a documentation procedure shown in table 4 is developed which helps reviewing teaching learning methods, course contents and assessment methods in case of any CLO failure.

Table 4. Curriculum mapping

\begin{tabular}{|c|c|c|c|c|c|}
\hline CLO's & PLO's & $\begin{array}{c}\text { Learning } \\
\text { Level }\end{array}$ & Course contents & $\begin{array}{l}\text { Teaching } \\
\text { methods }\end{array}$ & $\begin{array}{c}\text { Assessment } \\
\text { method }\end{array}$ \\
\hline 1 & a & $\begin{array}{l}\text { Under- } \\
\text { stand }\end{array}$ & $\begin{array}{l}\text { Introduction to MFCA, joining processes } \\
\text { and wear theory }\end{array}$ & $\begin{array}{c}\text { Lecture, } \\
\text { presentations, }\end{array}$ & $\begin{array}{l}\text { Quiz, Home } \\
\text { work }\end{array}$ \\
\hline 2 & $b$ & Apply & $\begin{array}{l}\text { Orthogonal Cutting Model in Machining, } \\
\text { Merchant Equation, Surface Finish and cut- } \\
\text { ting Tools Technology, Plastics extrusion, } \\
\text { sheet metal cutting }\end{array}$ & $\begin{array}{l}\text { Lectures, } \\
\text { presentation, } \\
\text { discussion }\end{array}$ & $\begin{array}{l}\text { Quiz, Home } \\
\text { work }\end{array}$ \\
\hline 3 & c & Evaluate & $\begin{array}{l}\text { Forces calculations in metal cutting for } \\
\text { evaluation, Forging analysis for pressure } \\
\text { evaluation in billets, sheet metal curting, } \\
\text { grinding or machining process evaluation }\end{array}$ & $\begin{array}{l}\text { Presentations, } \\
\text { discussion }\end{array}$ & $\begin{array}{l}\text { Quiz, Home } \\
\text { work, } \\
\text { Exam }\end{array}$ \\
\hline 4 & e & Create & Mini Project/Capstone project & Discussion & Presentation \\
\hline
\end{tabular}

Under a course offered by a degree program course learning outcomes are required to be directly and indirectly assessed and measured. Table 5 shows procedure assisting outcomes measurement process. Assessments are the instruments used by instructor to assess student's skills. One assessment method used for assessing a CLO is suggested but in present case instructor used more than one method to assess single CLO's. Table 5 shows a matrix linking assessment questions to CLO's to measure each CLO separately in addition with performance criteria for each assessment. 
Table 5. Mapping assessments with CLO's

\begin{tabular}{|c|c|c|c|c|}
\hline \multicolumn{2}{|c|}{$\begin{array}{l}\text { Assessment } \\
\text { techniques }\end{array}$} & \multirow{2}{*}{$\begin{array}{c}\text { question } \\
5 \mathrm{Qs}\end{array}$} & \multirow{2}{*}{$\begin{array}{c}\text { CLO } \\
2\end{array}$} & \multirow[b]{2}{*}{$\begin{array}{l}\text { an ability to apply knowledge of mathematics, science and engineering to } \\
\text { solve complex problems }\end{array}$} \\
\hline \multirow{3}{*}{$\begin{array}{l}\text { Home } \\
\text { work }\end{array}$} & HW 1 & & & \\
\hline & HW 2 & $5 \mathrm{Qs}$ & 2 & an ability to identify, formulate, solve and analyze engineering problems \\
\hline & HW 3 & $5 \mathrm{Qs}$ & 2,3 & $\begin{array}{l}\text { an ability to create, select and apply appropriate techniques, skills, and } \\
\text { modern engineering tools necessary for engineering practice }\end{array}$ \\
\hline \multirow{3}{*}{ Quiz } & Quiz 1 & $2 \mathrm{Qs}$ & 1,2 & $\begin{array}{l}\text { an ability to apply knowledge of mathematics, science and engineering to } \\
\text { solve complex problems }\end{array}$ \\
\hline & Quiz 2 & $2 \mathrm{Qs}$ & 2 & an ability to identify, formulate, solve and analyze engineering problems \\
\hline & Quiz 3 & $2 \mathrm{Qs}$ & 3 & $\begin{array}{l}\text { an ability to create, select and apply appropriate techniques, skills, and } \\
\text { modern engineering tools necessary for engineering practice }\end{array}$ \\
\hline \multirow{6}{*}{ Exam } & \multirow{6}{*}{$\begin{array}{l}\text { Mid- } \\
\text { term } \\
\text { exam }\end{array}$} & Q1 & -- & -- \\
\hline & & Q2 & 2 & \\
\hline & & Q3 & & an ability to identify, formulate, solve and analyze engineering problems \\
\hline & & Q4 & 3 & $\begin{array}{l}\text { an ability to create, select and apply appropriate techniques, skills, and } \\
\text { modern engineering tools }\end{array}$ \\
\hline & & Q5 & 3 & necessary for engineering practice \\
\hline & & Q6 & & \\
\hline \multirow[b]{2}{*}{$\begin{array}{l}\text { Any } \\
\text { other }\end{array}$} & \multirow[b]{2}{*}{$\begin{array}{l}\text { Mini } \\
\text { Project }\end{array}$} & & & $\begin{array}{l}\text { ability to create, select and apply appropriate techniques, skills, and mod- } \\
\text { ern engineering tools necessary for engineering practice }\end{array}$ \\
\hline & & -- & 4 & $\begin{array}{l}\text { ability to apply reasoning informed by contextual knowledge to assess } \\
\text { societal, health, safety, legal and cultural issues and the consequent re- } \\
\text { sponsibilities relevant to professional engineering practice and solutions } \\
\text { to complex engineering problems }\end{array}$ \\
\hline
\end{tabular}

\subsection{Outcome assessment}

Course instructors must decide to setup instruments to assess course learning outcomes in their course. In present case Student's skills and abilities are directly assessed by homework's, quizzes, exams and projects.

Indirect assessments are student's perception based assessments on their outcomes achievement and understanding. Program learning outcomes (PLO's)and course learning outcomes (CLO's) are indirectly assessed by student's satisfaction survey conducted after course completion. Student satisfaction survey was composed of two parts;1) Achieving of learning outcomes 2) course management. For this purpose likert scale (1-5) was used and students were asked to rate understanding of each CLO and PLO and course management which is described later.

To evaluate student's outcomes a threshold indicator is required to make sure achievement of outcomes up to a certain level. This is to mention that student needs to obtain 60 percent marks to achieve desired program and course learning outcomes while 60 percent students must achieve course and program learning outcomes for a course to be successful. To measure particular course learning outcomes for a student rmarks obtained by student are tabulated in excel form and then converted to percentage form. Then successful student's percentage for particular CLO under the course is calculated to find achievement. Achievement indicators for outcomes are as follows:

$$
\begin{array}{lll}
\text { - } & 90-100 \% & \text { fully achieved } \\
\text { - } & 80-90 \% & \text { excellently achieved } \\
\text { - } & 70-80 \% & \text { achieved } \\
\text { - } & \text { Below } 60 \% & \text { satisfactoilry achieved } \\
\text { In case of course learning outcome }
\end{array}
$$
(CLO's) correlation with single program learning outcome (PLO's) its data is directly used for PLO measurement but in multiple CLO's correlation with single PLO case, weight must be defined for each CLO i.e. Percentage contribution of CLO to achieve corresponding 
PLO and final marks are composite sum of individual CLO's at specific percentage and normalized to 100 percent. PLO achievement percentage is then measured by accumulating relevant CLO's data according to defined weights. Present case is an example of single CLO's correlation with PLO. Mathematical model for PLO measurement is given below

Step 1: $\forall \quad i$ determine percentage scores of students

Step 2: $\forall i$ compute the average percentage of scores to get $\mathrm{ACO}_{i}$ average points

Step 3: $\forall i$ assign percentage weightages $w$ to each $j$

Step 4: Compute the sum of weightages by

$$
\sum_{i=1}^{C} w_{i j}, \forall j
$$

Step 5: Compute the sum of $\sum_{i=1}^{C} w_{i j} \times A C O_{i}, \forall j$

Step 6: Get the PO contribution by

$$
\frac{\sum_{i=1}^{C} w_{i j} \times A C O_{i}}{\sum_{i=1}^{C} w_{i j}}, \forall j
$$

\section{RESULTS AND ANALYSIS}

Figure 2 shows outcomes achievement for "Metal forming and cutting analysis" course. As course learning outcomes (CLO's) mapping with program learning outcomes (PLO's) shows one to one correspondence so the graph shows results for both PLO's and CLO's. It can be seen from figure 2 that successful student's percentage is greater than $60 \%$ for all PLO's so the course is successfully completed with achievement of all CLO's and PLO's.

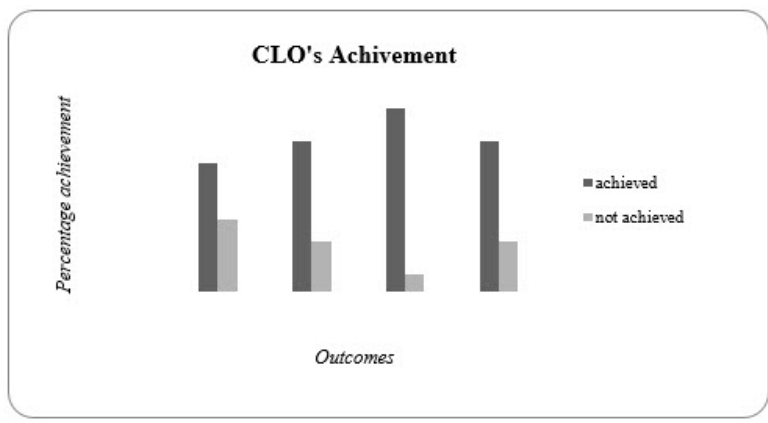

Figure 2. Course Learning Outcomes attainment

\subsection{Direct and indirect assessments result comparison}

Direct and indirect assessments need same basis of performance indicators to allow comparison. So Direct assessments percentage marks were converted to indirect assessment scale. For this purpose students percentage marks were divided by 20 to convert in to a linier scale i.e. 1 - 5. Performance indicators for assessments are set as: For an outcome to be successful both direct and indirect assessment calculated value must be greater than three. Direct and indirect assessment results agree with indirect assessment results as given in table 6 and 7 which show students actual learning and understanding. It is evident to say that direct and indirect assessments are the instruments to assess student's outcomes.

Table 6. CLO's direct and indirect assessment comparison

\begin{tabular}{cccccc}
\hline \multirow{2}{*}{ CLO } & \multicolumn{2}{c}{ Direct assessment } & \multicolumn{2}{c}{ Indirect Assessment } & Remarks \\
\cline { 2 - 6 } & $\begin{array}{c}\text { Successful } \\
\text { students \% }\end{array}$ & Scale=5 & Mean & $\begin{array}{r}\text { Standard } \\
\text { deviation }\end{array}$ & \\
\hline 1 & 63 & 3.1 & 4.3 & 0.8 & Successful \\
2 & 75 & 3.7 & 4.3 & 0.6 & Successful \\
3 & 91 & 4.5 & 4.3 & 0.6 & Successful \\
4 & 75 & 3.7 & 4.1 & 0.6 & Successful \\
\hline
\end{tabular}

Table 7. PLO's direct and indirect as-

\begin{tabular}{|c|c|c|c|c|c|}
\hline \multirow[b]{2}{*}{ PLO } & \multicolumn{2}{|c|}{ Direct assessment } & \multicolumn{2}{|c|}{ Indirect assessment } & \multirow[t]{2}{*}{ Remarks } \\
\hline & $\begin{array}{r}\text { Successful } \\
\text { students \% }\end{array}$ & Scale $=5$ & Mean & $\begin{array}{l}\text { Standard } \\
\text { deviation }\end{array}$ & \\
\hline $\mathrm{a}$ & 63 & 3.1 & 4.2 & 0.7 & Successful \\
\hline $\mathrm{b}$ & 75 & 3.7 & 4.3 & 0.7 & Successful \\
\hline c & 91 & 4.5 & 4.0 & 0.9 & Successful \\
\hline $\mathrm{e}$ & 75 & 3.7 & 4.0 & 0.9 & Successful \\
\hline
\end{tabular}
sessment comparison

\subsection{Measuring Course level by using Bloom's taxonomy}

Engineering courses are being taught in an order of learning level and complexity i.e. higher learning level course is offered in higher semester. Continuous quality improvement calls a procedure for course learning level assessment for each course offered. To ensure the achievement of acceptable course level by an 6instructor, selected course learning level was examined by mapping assessment questions to Blooms taxonomy. The frequencies of cognitive levels of assessment questions are given in table 8 for the specific course. It can be seen that $52 \%$ questions used for assessments were at understanding level, $8.6 \%$ at application level and analyzing level, $21 \%$ at evaluation level and only $8.6 \%$ at synthesis level. Maximum marks percentage of each cognitive level 
was evaluated. It can be established from table 8 that the course "metal forming and cutting analysis" was taught at $5^{\text {th }}$ level of learning.

Table 8. Assessing course learning level

\begin{tabular}{lcccc}
\hline $\begin{array}{c}\text { Questions Level } \\
\text { (Blooms) }\end{array}$ & $\begin{array}{c}\text { Questions } \\
\text { frequency }\end{array}$ & Percentage & $\begin{array}{c}\text { Max } \\
\text { marks }\end{array}$ & Percentage \\
\hline Knowledge & 0 & 0 & 0 & 0 \\
understanding & 12 & 52.17 & 5.75 & 19.16 \\
applying & 2 & 8.6 & 1 & 3.3 \\
analyzing & 2 & 8.6 & 8 & 42.6 \\
evaluation & 5 & 21.7 & 12.25 & 40.8 \\
synthesis & 2 & 8.6 & 8 & 26.6 \\
total & 23 & 100 & 30 & 100 \\
\hline
\end{tabular}

\subsection{Course evaluation}

Review of literature resulted in factors affecting student's performance as shown in table 9 which are categorized into two parts: (1) outcomes and (2) course management. Former assesses course and program learning outcomes while later assess course contents, teaching learning methods and assessment methods. To assess course management Likert scale 1-5 has been used. Table 9 details the means scores and standard deviation obtained in result of course evaluation survey analysis after course completion.

Table 9. Course Evaluation survey

\begin{tabular}{|c|c|c|c|}
\hline \multicolumn{2}{|c|}{ Factors affecting student performance } & \multirow{2}{*}{$\begin{array}{l}\text { Mean } \\
4.0\end{array}$} & \multirow{2}{*}{$\frac{\text { SD }}{0.7}$} \\
\hline $\begin{array}{l}\text { Course } \\
\text { objective }\end{array}$ & * Clearly expressed & & \\
\hline PLO & * Attainment & 3.8 & 0.8 \\
\hline $\begin{array}{l}\text { Course } \\
\text { contents }\end{array}$ & $\begin{array}{l}\text { * Strengthened course un- } \\
\text { derstanding } \\
* \quad \text { Helped achieving course } \\
\text { objectives } \\
* \quad \text { Comprehensive }\end{array}$ & 4.0 & 0.8 \\
\hline $\begin{array}{l}\text { Teaching } \\
\text { learning } \\
\text { methods }\end{array}$ & $\begin{array}{l}\text { Enhanced skills and abil- } \\
\text { ities relevant to course }\end{array}$ & 4.1 & 0.9 \\
\hline $\begin{array}{l}\text { Assess- } \\
\text { ments }\end{array}$ & $\begin{array}{l}\text { * assessed CLO's } \\
* \quad \text { assessed Strength and } \\
\text { weakness } \\
* \quad \text { helped Learning } \\
\text { * Level was appropriate to } \\
\text { given credit, }\end{array}$ & 3.9 & 0.9 \\
\hline CLO & * Attainment assessment & 4.02 & 0.8 \\
\hline
\end{tabular}

\subsection{Teacher Evaluation}

Review of literature resulted in multiple teacher traits resulting positive students learning outcomes which can be stated as maintaining positive learning climate, class instructions, class management, and student involvement in class, teaching/learning and student differentiation. Table 10 details mean scores and standard deviation obtained in result of teacher evaluation after course completion.

Table 10. Teacher Evaluation survey

\begin{tabular}{|c|c|c|c|}
\hline \multicolumn{2}{|c|}{ Teachers traits affecting students performance } & Mean & SD \\
\hline Learning Climate & $\begin{array}{ll}* & \text { Student's respect } \\
* & \text { Relaxed learning environment } \\
* & \text { Support for Class participation } \\
* & \text { Student collaboration } \\
\end{array}$ & 4.6 & 0.6 \\
\hline Class instruction & $\begin{array}{ll}* & \text { Declared lesson objective } \\
* & \text { Well structured lesson } \\
* & \text { Communication skills } \\
* & \text { Students comprehension }\end{array}$ & 4.2 & 0.8 \\
\hline Class management & $\begin{array}{l}* \quad \text { Lecture's start and finish time } \\
* \quad \text { Appropriate Students progress evalua- } \\
\text { tion techniques } \\
* \quad \text { Class room rules }\end{array}$ & 4.2 & 0.7 \\
\hline $\begin{array}{l}\text { Student involvement in } \\
\text { class }\end{array}$ & $\begin{array}{l}\text { * Critical thinking encouragement by ask- } \\
\text { ing questions } \\
* \quad \text { Student's interest in class } \\
* \quad \text { Students competition }\end{array}$ & 4.1 & 0.7 \\
\hline Teaching as learning & $\begin{array}{l}* \quad \text { Encourage students to think on solutions } \\
* \quad \text { Apply learning practically } \\
* \quad \text { Problem solving strategies } \\
* \quad \text { Challenging assignments }\end{array}$ & 4.1 & 0.8 \\
\hline Student differentiation & $\begin{array}{l}\text { * Boost weak student's self confidence } \\
* \quad \text { Additional instructions time }\end{array}$ & 3.3 & 1.3 \\
\hline
\end{tabular}

\section{CONCLUSIONS}

Due to requirement imposed by Washington accord agreement, engineering education in Pakistan is in the phase of transformation from traditional education to object based education system. Program learning outcomes assessment and evaluation is mandatory now for all engineering programs in Pakistan. In order to ensure that the graduates of industrial engineering department have achieved program educational objectives, an outcomes based accreditation continuous improvement framework has been presented. The assessment of engineering courses with respect to learning outcomes and student's expectations is an important activity regarding course improvement. Therefore course learning outcomes were directly and indirectly assessed. It was found that the proposed method has the ability to gauge achievement of student's outcomes. Strengths of the model include; (i) 
clearly defined performance criteria which are evidence for specific program educational objective, (ii) performance criteria is linked with evidence, (iii) use of performance indicators instead of grades.

Continuous quality improvement can be implemented based on these strengths. Proposed method is a close loop model equipped with continuous quality improvement.

\section{SUGGESTIONS AND RECOMMENDATIONS}

The findings of this research include:

- The developed framework facilitates continuous quality improvement while developed forms and procedures assess students' outcomes.

- Student exit, alumni and employer surveys are tools to evaluate outcomes at program level while course evaluation survey is an instrument to evaluate outcomes at course level.

- Student exit, teacher evaluation, and course evaluation survey are instruments to improve educational processes assisting attain educational objectives

- Program goals committee evaluates and monitors outcomes at program level while educational processes and facilities committee evaluate and monitor program performance by conducting surveys. Continuous course quality improvement committee is recommended to overcome course weaknesses.

Procedure to improve course followed by Program outcomes assessment tools are described below

\subsection{Continuous course quality improvement}

The results analysis section showed both direct and indirect measures for the course selected. It is evident from direct and indirect measures that course is successful but some percentage of students failed in program learning outcome "a", "b", "c" and "e". There is need for continuous course quality improvement monitored by CCQI committee to minimize failure percentage for same course next time. Given below methods are recommended/ suggested to figure out failure reasons.

\subsubsection{Failure patterns}

To address this issue continuous course improvement committee (CCQI) committee systematically must use set of information related to course and its prerequisite's course:

(1) outcomes correlation with the prerequisite and present course

(2) Students failure percentage in prerequisite

(3) switch from very low learning level (for pre-requisite) to very high learning level (present course)

(4) pre-requisite Course contents

(5) Level assessed in pre-requisite course exams.

\subsubsection{Issues related to student failure}

Survey may help identify issues related to student failure i.e. poor course management or student's personal problems. In case of poor course management actions must be taken to improve course.

\subsection{Program Learning Outcomes (PLO's) and Program Educational Objectives (PEO's) assessment tools}

Program learning outcomes and program educational objectives need to be continuously assessed and monitored. Several tools have been developed to indirectly assess student's outcomes at the time and after degree completion. Following section describe complete details of tools used for indirect assessment.

\subsubsection{Student Exit survey}

Review of literature resulted in number of factors affecting academic institutions performance and highlighted significance of student exit survey to evaluate institution performance and assess student's outcomes. Factors affecting academic performance can be stated as: (1) Education quality (2) Facilities and (3) Curriculum. Student exit form has been developed and categorized in to two sections: (1) Assessment of outcomes and (2) Academic performance evaluation. Table 10 show all factors enclosed in student exit survey in detail. 


\subsubsection{Alumni survey}

Alumni form also consists of two sections: (1) PEO's assessment and (2) alumni career. First section assesses outcomes while second section deals with graduate satisfaction with career, employment status, confidence in work and commitment to lifelong learning. Table 10 show all factors enclosed in Alumni survey in detail.

\subsubsection{Employer survey}

Employer form has been developed to collect employer's views about alumni performance, employed at industries in addition with industry demands i.e. which skills employers demand for an engineer to be employed at their organizations. Program educational objectives and program learning outcomes assessment in addition with modification to compete globally is purpose of employer form as shown in table 11 .

Table 11. Student exit, Alumni and Employer survey

\begin{tabular}{|c|c|c|}
\hline \multirow{6}{*}{ 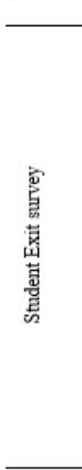 } & & actors \\
\hline & $\begin{array}{l}\text { Knowledge Skills and } \\
\text { attributes }\end{array}$ & $\begin{array}{ll}\text { - } & \text { clearly declared } \\
\text { - } & \text { Attainment assessment } \\
\text { - } & \text { Modify /delete/add } \\
\end{array}$ \\
\hline & Education quality & $\begin{array}{l}\text { - Instructions quality and knowledge } \\
\text { - Professional practices development }\end{array}$ \\
\hline & Facilities & $\begin{array}{l}\text { - Computational facilities } \\
\text { - Laboratory facilities } \\
\text { - Equipment needed for a modem education } \\
\text { - Library holdings }\end{array}$ \\
\hline & Curriculum & $\begin{array}{l}\text { - Team projects and discussions } \\
\text { - Missing material } \\
\text { - Unnecessary material } \\
\text { - Career development }\end{array}$ \\
\hline & General opinions & - Important skills leamed during graduation \\
\hline \multirow{5}{*}{ 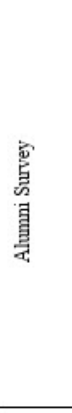 } & $\begin{array}{l}\text { program educational } \\
\text { objectives }\end{array}$ & $\begin{array}{l}\text { - Meet newly admitted students } \\
\text { - Modify/ delete / add }\end{array}$ \\
\hline & Satisfaction with career & $\begin{array}{l}\text { - Current employment position } \\
\text { - Successful Career }\end{array}$ \\
\hline & $\begin{array}{l}\text { Graduate employment } \\
\text { statuses }\end{array}$ & - Find job within 1 year after graduation \\
\hline & Confidence in work & $\begin{array}{l}\text { - Job is closely related to education } \\
\text { - Skills fulfill job demand } \\
\text { - Engineering courses that need improve- } \\
\text { ments } \\
\text { - Missing material } \\
\end{array}$ \\
\hline & $\begin{array}{l}\text { Commitment to life- } \\
\text { long learning }\end{array}$ & $\begin{array}{l}\text { - professional society member } \\
\text { - Enrolled in education }\end{array}$ \\
\hline \multirow{3}{*}{ 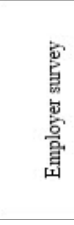 } & $\begin{array}{l}\text { Knowledge Skills and } \\
\text { attributes }\end{array}$ & $\begin{array}{l}\text { - Academic and professional preparation } \\
\text { - Industrial skills demand } \\
\text { - } \quad \text { Modify/delete/ add } \\
\end{array}$ \\
\hline & $\begin{array}{l}\text { Program educational } \\
\text { objectives }\end{array}$ & $\begin{array}{l}\text { - Role in global Business } \\
\text { - Attainment assessment } \\
\text { - } \text { Modify/delete/add } \\
\end{array}$ \\
\hline & General assessment & - Suggestions to improve \\
\hline
\end{tabular}

\section{ACKNOWLEDGEMENTS}

The authors would like to record their appreciation to the Head of Industrial Engineering Department, University of Engineering and Technology Taxila (Pakistan) for funding this research. They also wish to thank all the participants who responded timely and provided their feedback.

\section{Conflict of interests}

The authors declare no conflict of interest.

\section{REFERENCES}

Almarshoud, A. F. (2011). Developing a rubric-based framework for measuring the ABET outcomes achieved by students of electric machinery courses. International Journal of Engineering Education, 27(4), 859. http://www.ijee.ie/contents/c270411.html

Besterfield-Sacre, M., Shuman, L. J., \& Wolfe, H. (2002). Modeling undergraduate engineering outcomes. International Journal of Engineering Education, 18(2), 128-139. http://www.ijee.ie/ articles/Vol18-2/IJEE1269.pdf .

Blumenfeld, P. C., Soloway, E., Marx, R. W., Krajcik, J. S., Guzdial, M., \& Palincsar, A. (1991). Motivating project-based learning: Sustaining the doing, supporting the learning. Educational psychologist, 26(3-4), 369-398. http://dx.doi.org/10 $.1080 / 00461520.1991 .9653139$

Boerboom, T. B., Stalmeijer, R. E., Dolmans, D. H., \& Jaarsma, D. A. (2015). How feedback can foster professional growth of teachers in the clinical workplace: A review of the literature. Studies in Educational Evaluation, 46, 47-52. http:// dx.doi.org/10.1016/j.stueduc.2015.02.001

Borsoto, L. D., Lescano, J. D., Maquimot, N. I., Santorce, M. J. N., Simbulan, A. F., \& Pagcaliwagan, A. M. (2014). Status Of Implementation And Usefulness Of Outcomes-Based Education In The Engineering Department Of An Asian University. Asian Journal of Management Science and Economics, 1(1). http://www. multidisciplinaryjournals.com/wp-content/uploads/2014/02/STATUS-OF-IMPLEMENTATION.pdf

Bouslama, F., Lansari, A., Al-Rawi, A., \& Abonamah, A. A. (2003). A novel outcome-based educational model and its effect on student learning, curriculum development, and assessment. Journal of Information Technology Education, 2, 203-214. http://www.jite.informingscience.org/ documents/Vol2/v2p203-214-22.pdf

Bresciani, M. J. (2006). Outcomes-based academic and co-curricular program review: A compilation of institutional good practices. Stylus Publishing, LLC. (ISBN: 1-57922-140-8).

Chalmers, D., \& Gardiner, D. (2015). An evaluation framework for identifying the effectiveness and impact of academic teacher development programmes. Studies in Educational Evaluation, 46, 81-91. http://dx.doi.org/10.1016/j.stueduc.2015.02.002 
Davis, M. H. (2003). Outcome-based education. Journal of veterinary medical education, 30(3), 258263. http://dx.doi.org/10.3138/jvme.30.3.258

Jahanzaib, M., \& Akhtar, K. (2005). Prioritizing key quality indicators for engineering education using analytical hierarchical process (AHP): Case study. (pp. 1-12). In Proceedings of Pakistan's 4th conference on quality assurance in education, organized by Pakistan Institute of Quality Control, Lahore on (pp. 17-18).

Kapfer, M. B. (1971). Behavioral objectives in curriculum development: selected readings and bibliography. Educational Technology. (ISBN: 0-87778-001-3)

King, J. A., \& Evans, K. M. (1991). Can we achieve outcome-based education. Educational Leadership, 49(2), 73-75. http://ascd.com/ASCD/pdf/ journals/ed lead/el 199110 king.pdf

Laguador, J. M., \& Dotong, C. I. (2014). Knowledge versus Practice on the Outcomes-Based Education Implementation of the Engineering Faculty Members in LPU. International Journal of Academic Research in Progressive Education and Development, 3(1), 63-74. http://dx.doi.org/ 10.6007/IJARPED/v3-i1/640

Learning, P. B. (2001). Speaking of Teaching. (Winter 2001, 11(1), 1-6. Stanford University Newsletter on Teaching. http://www.konstruktivismus. uni-koeln.de/didaktik/problembased/problem based learning.pdf

Majid, F. A. (2008). The use of reflective journals in outcome-based education during the teaching practicum. Malaysian Journal of ELT Research, 4. http://s3.amazonaws.com/academia.edu.docu-ments/13774581/faizah v2.pdf?AWSAcces sKeyId=AKIAJ56TQJRTWSMTNPEA\&Ex-pi res $=1483958766 \&$ Signature $=06 \mathrm{~K} 6 \mathrm{z} 8 \mathrm{lc} 2 \mathrm{P} 8 \mathrm{R}$ L1ggm6H1E6i9tcE\%3D\&response-con-tentdisposition=inline $\% 3 \mathrm{~B} \% 20$ filename $\% 3 \mathrm{DThe}$ Use of Reflective Journals in Outcom.pdf

Manual of accrediation Engineering Accrediation Board. (2014). Retrieved may 20, 2015, from http://www.pec.org.pk/downloadables/Accreditation/PEC\%20OBA-Manual\%202014.pdf

McGourty, J., Shuman, L., Besterfield-Sacre, M., Atman, C., Miller, R., Olds, B., ... \& Wolfe, H (2002). Preparing for ABET EC 2000: Researchbased assessment methods and processes. International Journal of Engineering Education, 18(2), 157-167. http://drjj.uitm.edu.my/DRJJ/ MQAGGPAS-Apr2011/ABET-LO-CRITERIA ABET-Assessment-IJEE1278.pdf

Mohammad, A. W., \& Zaharim, A. (2012). Programme outcomes assessment models in engineering faculties. Asian Social Science, 8(16), 115. http:// dx.doi.org/10.5539/ass.v8n16p115

Mokhtar, S. A., Puteh, S., \& Anuar, S. M. S. (2014). OBE Measurement System in Malaysian Institute of Information Technology Universiti Kuala Lumpur. In 2014 5th International Conference on Intelligent Systems, Modelling and Simulation (pp. 12-17). IEEE. http://dx.doi. org/10.1109/ISMS.2014.10

Othman, N. T. A., Misnon, R., Abdullah, S. R. S., Kofli, N. T., Kamarudin, S. K., \& Mohamad, A. B. (2011). Assessment of programme outcomes through exit survey of Chemical/Biochemical Engineering students. Procedia-Social and Behavioral Sciences, 18, 39-48. http://dx.doi. org/10.1016/j.sbspro.2011.05.007 .
Patil, A., \& Codner, G. (2007). Accreditation of engineering education: review, observations and proposal for global accreditation. European journal of engineering education, 32(6), 639-651. http:// dx.doi.org/10.1080/03043790701520594

Rajaee, N., Junaidi, E., Taib, S. N. L., Salleh, S. F., \& Munot, M. A. (2013). Issues and challenges in implementing outcome based education in engineering education. International Journal for Innovation Education and Research, 1(4), 1-9. http://ir.unimas.my/id/eprint/1168

Rashid, M. H. (2012). The Process of OutcomeBased Education-Implementation, Assessment and Evaluations, ASEE international forum, http://www.asee.org/public/conferences/27/papers $/ 8242 /$ view

Sekhar, C. R., Farook, O., \& Bouktache, E. (2008). Continuous improvement process based on outcome based education. In Proceedings of the 2008 IAJC-IJME International Conference. Accessed March (Vol. 5, p. 2013). http://www.ijme. us/cd 08/PDF/31 ENG107.pdf

Spady, W. G. (1994). Outcome-Based Education: Critical Issues and Answers. American Association of School Administrators. http://files.eric.ed.gov/ fulltext/ED380910.pdf

Spady, W. G., \& Marshall, K. J. (1991). Beyond Traditional Outcome-Based Education. Educational Leadership, 49(2), 67-72. https://eric. ed.gov/?id=EJ432789

Student Outcomes and Program Educational Objectives. (2015). Retrieved july 7, 2015, from http:/ miamioh.edu:http://miamioh.edu/cec/academics/departments/mme/about/student-outcomes/ index.html

White, H. (2001). Getting started in problem-based learning. The power of problem-based learning, 69-78. https://books.google.com.pk/books?hl=e $\mathrm{n} \& 1 \mathrm{r}=\& \mathrm{id}=5 \mathrm{gJu} 7 \mathrm{IKBC} 98 \mathrm{C} \& \mathrm{oi}=\mathrm{fnd} \& \mathrm{pg}=\mathrm{PA} 69$ $\&$ dq $=$ White,+ h. $+(2001) .+$ Problem + based + learn ing\&ots $=$ tD9n ot AbC\&sig $=$ FcjguN714fdt6UN vJFJn1R0AvpQ $\# \mathrm{v}=$ onepage\&q\& $\mathrm{f}=$ false

Volkwein, J. F., Lattuca, L. R., Terenzini, P. T., Strauss, L. C., \& Sukhbaatar, J. A. V. Z. A. N. (2004). Engineering change: A study of the impact of EC2000. International Journal of Engineering Education, 20(3), 318-328. http://www.ijee.ie/ articles/Vol20-3/IJEE2497.pdf 
Annexure 1. Correlation Matrix

\begin{tabular}{|c|c|c|c|c|c|c|c|c|c|c|c|c|}
\hline & Course & & & & Pr & am & earnin & ut & mes & & & \\
\hline $\begin{array}{l}\text { Course } \\
\text { Code }\end{array}$ & Course Title & a & $\mathrm{b}$ & c & d & e & $f$ & $\mathrm{~g}$ & $\mathrm{H}$ & $i$ & $\mathrm{j}$ & $\mathrm{k}$ \\
\hline IE-101 & $\begin{array}{l}\text { Problem Solving for } \\
\text { Industrial Engineers }\end{array}$ & SWC & SC & $\mathrm{NC}$ & SC & SC & SWC & $\mathrm{NC}$ & swC & SWC & SWC & SWC \\
\hline IE-102 & WorkShop Practice & SC & SC & SWC & $\mathrm{SC}$ & $\mathrm{SC}$ & $\mathrm{NC}$ & SWC & $\mathrm{SC}$ & $\mathrm{NC}$ & swC & swC \\
\hline ME-191 & $\begin{array}{l}\text { Engineering Drawing and } \\
\text { Graphics }\end{array}$ & $\mathrm{SC}$ & $\mathrm{SC}$ & SC & $\mathrm{NC}$ & SC & $\mathrm{NC}$ & $\mathrm{NC}$ & $\mathrm{NC}$ & $\mathrm{NC}$ & $\mathrm{NC}$ & SWC \\
\hline ME-292 & Mechanical Technology & $\mathrm{SC}$ & $\mathrm{SC}$ & $\mathrm{SC}$ & SC & SWC & $\mathrm{NC}$ & $\mathrm{NC}$ & $\mathrm{NC}$ & $\mathrm{NC}$ & swC & $\mathrm{NC}$ \\
\hline MA-191 & Calculus & $\mathrm{SC}$ & SC & $\mathrm{SC}$ & SWC & SC & $\mathrm{NC}$ & $\mathrm{NC}$ & $\mathrm{NC}$ & $\mathrm{NC}$ & SWC & $\mathrm{NC}$ \\
\hline MA-192 & Differential Equations & SC & $\mathrm{SC}$ & SC & SWC & SC & $\mathrm{NC}$ & $\mathrm{NC}$ & $\mathrm{NC}$ & $\mathrm{NC}$ & SWC & NC \\
\hline CS-192 & $\begin{array}{l}\text { Introduction to } \\
\text { Computing }\end{array}$ & $\mathrm{SC}$ & $\mathrm{SC}$ & SC & SwC & SC & $\mathrm{NC}$ & $\mathrm{NC}$ & $\mathrm{NC}$ & $\mathrm{NC}$ & SwC & SWC \\
\hline HU-112 & Islamic Studies / Ethics & $\mathrm{NC}$ & $\mathrm{NC}$ & $\mathrm{NC}$ & $\mathrm{NC}$ & NC & $\mathrm{NC}$ & SC & $\mathrm{NC}$ & SWC & $\mathrm{SC}$ & NC \\
\hline IE-121 & Probability and Statistics & $\mathrm{SC}$ & SC & SC & $\mathrm{SC}$ & swC & $\mathrm{NC}$ & $\mathrm{NC}$ & $\mathrm{NC}$ & $\mathrm{NC}$ & swC & $\mathrm{NC}$ \\
\hline IE-122 & $\begin{array}{l}\text { Computer Aided Design } \\
\& \text { Modeling }\end{array}$ & $\mathrm{SC}$ & SC & $\mathrm{SC}$ & $\mathrm{NC}$ & SC & $\mathrm{NC}$ & $\mathrm{NC}$ & swc & $\mathrm{NC}$ & $\mathrm{SC}$ & swC \\
\hline IE-231 & Engineering Management & $\mathrm{SC}$ & $\mathrm{SC}$ & $\mathrm{SC}$ & swC & SWC & SWC & SC & swc & SwC & $\mathrm{SC}$ & $\mathrm{NC}$ \\
\hline ME-221 & Engineering Mechanics & $\mathrm{SC}$ & $\mathrm{SC}$ & $\mathrm{SC}$ & swC & SC & $\mathrm{NC}$ & $\mathrm{NC}$ & $\mathrm{NC}$ & $\mathrm{NC}$ & SWC & $\mathrm{NC}$ \\
\hline HU-101 & Applied Physics & $\mathrm{SC}$ & $\mathrm{SC}$ & SC & SC & SWC & NC & $\mathrm{NC}$ & $\mathrm{NC}$ & $\mathrm{NC}$ & SWC & $\mathrm{NC}$ \\
\hline ME-293 & Materials Engineering & SC & $\mathrm{SC}$ & SC & SWC & $\mathrm{SC}$ & SWC & $\mathrm{NC}$ & $\mathrm{NC}$ & $\mathrm{NC}$ & SWC & SWC \\
\hline MA-193 & Applied Linear Algebra & $\mathrm{SC}$ & $\mathrm{SC}$ & $\mathrm{SC}$ & SWC & $\mathrm{SC}$ & $\mathrm{NC}$ & $\mathrm{NC}$ & $\mathrm{NC}$ & $\mathrm{NC}$ & swC & $\mathrm{NC}$ \\
\hline IE-241 & Ig Economics & $\mathrm{SC}$ & $\mathrm{SC}$ & $\mathrm{SC}$ & SWC & $\mathrm{SC}$ & $\mathrm{SC}$ & $\mathrm{NC}$ & SWC & $\mathrm{NC}$ & $\mathrm{NC}$ & SWC \\
\hline IE-243 & Operations Research & $\mathrm{SC}$ & $\mathrm{SC}$ & $\mathrm{SC}$ & swC & SC & SWC & $\mathrm{NC}$ & $\mathrm{NC}$ & $\mathrm{NC}$ & SwC & SWC \\
\hline IE-242 & Manufacturing Process & $\mathrm{SC}$ & $\mathrm{SC}$ & $\mathrm{SC}$ & $\mathrm{SC}$ & $\mathrm{SC}$ & SWC & $\mathrm{NC}$ & $\mathrm{NC}$ & $\mathrm{NC}$ & SWC & SWC \\
\hline HU-113 & Pakistan Studies & $\mathrm{NC}$ & $\mathrm{NC}$ & $\mathrm{NC}$ & $\mathrm{NC}$ & $\mathrm{NC}$ & $\mathrm{NC}$ & $\mathrm{SC}$ & $\mathrm{NC}$ & SC & SWC & $\mathrm{NC}$ \\
\hline ME-294 & Mechanics of Materials & $\mathrm{SC}$ & $\mathrm{SC}$ & SC & SC & SWC & SWC & $\mathrm{NC}$ & $\mathrm{NC}$ & $\mathrm{NC}$ & SWC & NC \\
\hline EE-301 & Industrial Electronics & $\mathrm{SC}$ & $\mathrm{SC}$ & $\mathrm{SC}$ & SWC & $\mathrm{SC}$ & $\mathrm{NC}$ & $\mathrm{NC}$ & $\mathrm{NC}$ & $\mathrm{NC}$ & SWC & SwC \\
\hline IE-311 & $\begin{array}{l}\text { Operations of } \\
\text { Manufacturing Systems }\end{array}$ & SC & $\mathrm{SC}$ & $\mathrm{SC}$ & swC & SC & SWC & $\mathrm{NC}$ & swc & $\mathrm{NC}$ & SWC & SWC \\
\hline ME-311 & $\begin{array}{l}\text { Applied Macl } \\
\text { \& FEM } 21\end{array}$ & $\mathrm{SC}$ & SC & SC & $\mathrm{SC}$ & SC & SWC & $\mathrm{NC}$ & swC & $\mathrm{NC}$ & swC & SWC \\
\hline IE-312 & $\begin{array}{l}\text { IE-312 Metrology \& } \\
\text { Statistical Quality Control } \\
31\end{array}$ & SC & SC & SC & swC & SC & $\mathrm{NC}$ & $\mathrm{NC}$ & $\mathrm{NC}$ & $\mathrm{NC}$ & $\mathrm{SC}$ & swC \\
\hline IE-313 & $\begin{array}{l}\text { IE-313 Optimization } \\
\text { Techniques } 20\end{array}$ & SC & $\overline{\mathrm{SC}}$ & 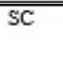 & SWC & SC & SWC & $\mathrm{NC}$ & $\mathrm{NC}$ & $\mathrm{NC}$ & SWC & SWC \\
\hline IE-314 & $\begin{array}{l}\text { IE-314 Work Study \& } \\
\text { Methods Engineering }\end{array}$ & SC & $\mathrm{SC}$ & SC & SWC & $\mathrm{SC}$ & SWC & $\mathrm{NC}$ & SWC & SWC & SWC & SWC \\
\hline IE-321 & Industrial Simulation 21 & SC & SC & $\mathrm{SC}$ & SWC & $\mathrm{SC}$ & SWC & $\mathrm{NC}$ & SWC & $\mathrm{NC}$ & $\mathrm{SC}$ & SWC \\
\hline IE-322 & $\begin{array}{l}\text { IE-322 Human Factors } \\
\text { Engineering } 21\end{array}$ & SC & $\mathrm{SC}$ & $\mathrm{SC}$ & SWC & SWC & SC & SWC & SWC & SWC & $\mathrm{SC}$ & SWC \\
\hline IE-323 & $\begin{array}{l}\text { IE-323 Management of } \\
\text { Engineering Projects } 30\end{array}$ & SWC & $\mathrm{SC}$ & SWC & SWC & $\mathrm{SC}$ & SWC & SWC & SC & $\mathrm{SC}$ & SWC & SWC \\
\hline MA-391 & $\begin{array}{l}\text { MA-391 Numerical } \\
\text { Analysis } 30\end{array}$ & SC & $\mathrm{SC}$ & $\mathrm{SC}$ & SWC & $\mathrm{SC}$ & $\mathrm{NC}$ & $\mathrm{NC}$ & $\mathrm{NC}$ & $\mathrm{NC}$ & SWC & $\mathrm{NC}$ \\
\hline IE-324 & $\begin{array}{l}\text { Planning \& Scheduling in } \\
\text { Manufacturing } 20\end{array}$ & SC & $\mathrm{SC}$ & $\mathrm{SC}$ & SWC & $\mathrm{SC}$ & SWC & $\mathrm{NC}$ & SWC & $\mathrm{NC}$ & swC & SwC \\
\hline IE-325 & $\begin{array}{l}\text { Industrial Automation } \\
\text { and Robotics }\end{array}$ & SC & $\mathrm{SC}$ & $\mathrm{SC}$ & SWC & SC & SC & $\mathrm{NC}$ & SWC & $\mathrm{NC}$ & SC & SWC \\
\hline IE-411 & $\begin{array}{l}\text { Design of Experiments } 3 \\
1\end{array}$ & SC & $\mathrm{SC}$ & $\mathrm{SC}$ & $\mathrm{SC}$ & $\mathrm{SC}$ & $\mathrm{SC}$ & $\mathrm{NC}$ & SWC & $\mathrm{NC}$ & $\mathrm{SC}$ & SWC \\
\hline IE-412 & $\begin{array}{l}\text { IE-412 Industrial } \\
\text { Facilities Design } 21\end{array}$ & SC & $\mathrm{SC}$ & $\mathrm{SC}$ & SWC & $\mathrm{SC}$ & $\mathrm{SC}$ & $\mathrm{NC}$ & SWC & $\mathrm{NC}$ & SWC & SWC \\
\hline IE-XXX & $\begin{array}{l}\text { IE-XXX Elective I } \\
\text { (HRM) }\end{array}$ & SWC & SWC & SWC & swC & $\mathrm{SC}$ & SWC & SWC & $\mathrm{SC}$ & SC & SWC & SWC \\
\hline IE-XXX & $\begin{array}{l}\text { IE-XXX Elective II } \\
\text { (Metal forming an cutting } \\
\text { analysis }\end{array}$ & $\mathrm{SC}$ & SC & $\mathrm{SC}$ & SWC & SC & $\mathrm{SC}$ & NC & $\mathrm{NC}$ & $\mathrm{NC}$ & SWC & SWC \\
\hline IE-49] & IE-491 Project Phase I & SC & $\mathrm{SC}$ & $\mathrm{SC}$ & $\mathrm{SC}$ & $\mathrm{SC}$ & SC & $\mathrm{SC}$ & SC & $\mathrm{SC}$ & $\mathrm{SC}$ & $\mathrm{SC}$ \\
\hline IE-XXX & $\begin{array}{l}\text { Elective I (Organizational } \\
\text { behavior }\end{array}$ & SWC & SWC & SWC & SWC & SWC & SWC & $\mathrm{SC}$ & SC & SWC & SWC & SWC \\
\hline IE-XXX & $\begin{array}{l}\text { IE-XXX Elective I } \\
\text { (Automation and ctrl) }\end{array}$ & SC & SC & SC & SWC & $\mathrm{SC}$ & SC & $\mathrm{NC}$ & SWC & $\mathrm{NC}$ & SC & SWC \\
\hline IE-XXX & $\begin{array}{l}\text { IE-XXX Elective II } \\
\text { (CIM) }\end{array}$ & SC & $\mathrm{SC}$ & $\mathrm{SC}$ & SWC & $\mathrm{SC}$ & $\mathrm{SC}$ & $\mathrm{NC}$ & swC & $\mathrm{NC}$ & SC & SWC \\
\hline IE-XXX & IE-XXX Elective & & & & & & & & & & & \\
\hline IE-492 & IE-492 Project Phase II & SC & $\mathrm{SC}$ & SC & SC & $\mathrm{SC}$ & $\mathrm{SC}$ & $\mathrm{SC}$ & $\mathrm{SC}$ & $\mathrm{SC}$ & $\mathrm{SC}$ & $\mathrm{SC}$ \\
\hline
\end{tabular}

SC: Strongly correlated, SWC: Somewhat correlated, NC: Not correlated 